\title{
SISTEM PENYEWAAN GEDUNG SERBAGUNA DI MASJID AGUNG AL-BARKAH BEKASI
}

\author{
${ }^{1}$ Nurul Aisyah, SE., MM., ${ }^{2}$ Asep, SE., MM, ${ }^{3}$ Ani Yoraeni \\ Email: ${ }^{1}$ nurul.nly@bsi.ac.id, ${ }^{2}$ asep.aep@bsi.ac.id, ${ }^{3}$ ani.ayr@bsi.ac.id
}

\begin{abstract}
Abstrak
Gedung pertemuan merupakan suatu tempat layanan bagi orang-orang yang ingin menggelar suatu acara. Untuk memberikan layanan yang optimal serta memuaskan, dibutuhkan suatu kerjasama yang saling kondusif di berbagai bidang. Seiring dengan kemajuan teknologi, maka berbagai perusahaan yang mengelola gedung pertemuan tersebuat membutuhkan suatu sistem yang memudahkan mereka untuk melihat kesiapan gedung yang akan digunakan untuk menggelar suatu acara. Masjid Agung Al-Barkah merupakan sebagai Masjid Pusat Syiar dan Dakwah Islam, dengan visi An-Nashiruth Thagyir (pusat perubahan) bermanfaat guna kepentingan umat islam khususnya di Kota Bekasi. Disamping itu Gedung Serbaguna Al-Barkah, merupakan bangunan Masjid lama yang sudah direnovasi sedemikian rupa yang letaknya sebelah barat Masjid dan untuk memenuhi keinginan dan harapan masyarakat maka Masjid Agung Al-Barkah menyediakan jasa penyewaan gedung untuk berbagai acara. Untuk membuat sistem penyewaan gedung di Masjid Agung AlBarkah, Menggunakan sistem Unified Modelling Language(UML), Diagram UML. maka Penyajian sistem penyewaan gedung serbaguna dengan cara pemesanan, pembayaran yang masih dilakukan secara manual bisa terdap at resiko kesalahan dalam pencatatan, dalam mengelola penyewaan gedung serbaguna.
\end{abstract}

Kata kunci: sistem penyewaan gedung.

\section{Abstract}

The meeting hall is a service place for people who want to hold an event. To provide optimal and satisfying services, a mutually conducive collaboration is needed in various fields. As technology advances, companies that manage meetinghouses need a sistem that makes it easy for them to see the readiness of the building to be used to hold an event. Al-Barkah Great Mosque is the Central Mosque of Shiar and Da'wah of Islam, with the vision of An-Nashiruth Thagyir (center of change) useful for the interests of Muslims, especially in the City of Bekasi. Besides that the AlBarkah Multipurpose Building, is an old mosque building that has been renovated in such a way that is located west of the Mosque and to fulfill the wishes and expectations of the people, the AlBarkah Great Mosque provides building rental services for various events. To create a sistem of leasing buildings in the Great Mosque of Al-Barkah, using the Unified Modeling Language (UML) sistem, UML diagram. then the presentation of a multipurpose building rental sistem by way of ordering, payments that are still done manually can be a risk of errors in recording, in managing the leasing of multipurpose buildings

Keywords: Rental sistem building 


\section{Pendahuluan}

Gedung pertemuan merupakan suatu tempat layanan bagi orang-orang yang ingin menggelar suatu acara. Untuk memberikan layanan yang optimal serta memuaskan, dibutuhkan suatu kerjasama yang saling kondusif di berbagai bidang. Seiring dengan kemajuan teknologi, maka berbagai perusahaan yang mengelola gedung pertemuan tersebuat membutuhkan suatu sistem yang memudahkan mereka untuk melihat kesiapan gedung yang akan digunakan untuk menggelar suatu acara.

Masjid Agung Al-Barkah merupakan sebagai Masjid Pusat Syiar dan Dakwah Islam, dengan visi An-Nashiruth Thagyir (pusat perubahan) bermanfaat guna kepentingan umat islam khususnya di Kota Bekasi. Disamping itu Gedung Serbaguna Al-Barkah, merupakan bangunan Masjid lama yang sudah direnovasi sedemikian rupa yang letaknya sebelah barat Masjid dan untuk memenuhi keinginan dan harapan masyarakat maka Masjid Agung AlBarkah menyediakan jasa penyewaan gedung untuk berbagai acara.

Jasa sewa ini dimaksudkan bagi penyewa untuk sebuah persetujuan dimana sebuah pembayaran dilakukan atas penggunaan suatu barang atau property secara sementara oleh orang lain. Barang yang dapat disewa bermacam-macam, tarif dan lama sewa juga bermacam- macam. Dalam penyewaan ini banyak penyewa yang kadang kesulitan dalam menyimpan suatu informasi guna jalannya sewa menyewa, maka perlunya sebuah sistem yang mengatur untuk usaha penyewaan tersebut. Sistem merupakan suatu susunan yang teratur dari kegiatan yang saling berkaitan dan susunan prosedur yang saling berhubungan, yang melaksanakan dan mempermudah kegiatankegiatan utama suatu organisasi.

Pada saat ini, Gedung Serbaguna AlBarkah masih menggunakan sistem yang belum berbasis komputerisasi, khususnya didalam mengelola sistem informasi penyewaan gedung yang akan digunakan. Maka penulis mengambil judul "Sistem Penyewaan Gedung serbaguna di Masjid Agung Al-Barkah Bekasi".

\section{Tinjauan Pustaka}

\section{Konsep dasar Sistem \\ Definisi Sistem}

Berikut ini adalah beberapa definisi sistem menurut beberapa ahli, di antaranya adalah:

1. Menurut Bambang, (2016:10), Bonita J. Campbel dalam buku Understanding Information Sistem: Foundations for control menegaskan bahwa "sistem adalah "any group of interrelated components or parts which function together to achieve goal" (Sehimpunan bagian-bagian atau komponen yang saling berkaitan dan secara bersamasama berfungsi atau bergerak untuk mencapai suatu tujuan).

2. Dikutip dari buku Bambang (2016:10) mendefinisikan sistem sebagai "any collection of componnet that work togenther to achieve a common objective" (Sekumpulan komponen yang secara bersama-sama bekerja untuk mencapai suatu tujuan bersama).

\section{Karakteristik Sistem}

Menurut Jogiyanto, sebuah sistem memiliki paling sedikit sepuluh karakteristik berikut.

1. Komponen (components). Bagian-bagian atau elemen-elemen, yang dapat berupa benda atau manusia, berbentuk nyata atau abstrak, dan disebut subsistem.

2. Penghubung antarbagian (interface). Sesuatu yang bertugas menjembatani satu bagian dengan bagian lain, dan memungkinkan terjadinya interaksi/komunikasi antarbagian.

3. Batas (boundary). Sesuatu yang membedakan antara sistem dengan sistem atau sistem-sistem lain.

4. Lingkungan (environment). Segala sesuatu yang berada di luar sistem dan dapat bersifat menguntungkan atau merugikan sistem yang bersangkutan.

5. Masukan (input). Sesuatu yang merupakan bahan untuk diolah atau diproses oleh sistem.

6. Mekanisme pengolahan (processing). Perangkat dan prosedur untuk mengubah 
masukan menjadi keluaran dan menampilkannya.

7. Keluaran (output). Berbagai macam bentuk hasil atau produk yang dikeluarkan dari pengolahan.

8. Tujuan (goal/objective). Sesuatu atau keadaan yang ingin dicapai oleh sistem, baik dalam jangka pendek maupun jangka panjang.

9. Sensor dan kendali (sensor \& control). Sesuatu yang bertugas memantau dan menginformasikan perubahan-perubahan di dalam lingkungan dan dalam diri sistem kepada sistem.

10.Umpan-balik (feedback). Informasi tentang perubahan-perubahan lingkungan dan perubahan-perubahan (penyimpangan) dalam diri sistem.

\section{Klasifikasi Sistem}

Suatu sistem dapat diklasifikasikan sebagai sistem abstrak (abstract) lawan sistem fisik (physical sistem), sistem alamiah (natural sistem) lawan sistem buatan manusia (human made sistem), sistem pasti (deterministic sistem) lawan sistem probabilistik (probabilistic sistem), dan sistem tertutup (closed sistem) lawan sistem terbuka (open sistem).

Sistem informasi masuk di dalam klasifikasi sistem fisik, sistem buatan manusia, sistem pasti dan sistem terbuka. Sebagai sistem fisik, sistem informasi mempunyai komponenkomponen fisik. Sebagai sistem buatan manusia, karena dirancang dan dibuat oleh analis atau pemakai sistem. Sebagai sistem pasti, karena hasil dari sistem ini yang berupa informasi merupakan hasil yang sudah dirancang dan sudah ditentukan dengan sesuai dengan pemakainya. Sebagai sistem yang terbuka, karena sistem ini berhubungan dengan lingkungan luarnya. Lingkungan luar sistem informasi dapat berupa sesuatu di luar sistem informasi ini tetapi masih di lingkungan atau sesuatu di luar lingkungan perusahaannya.

\section{Peralatan Pendukung}

Merupakan alat yang digunakan untuk menggambarkan bentuk logika model dari suatu sistem dengan menggunakan simbol-simbol, lambang-lambang, diagram-diagram yang menunjukan secara tepat arti dan fungsinya. Adapun peralatan pendukung (tools sistem) yang dijelaskan sebagai model sistem yang akan dirancang adalah sebagai berikut :

Definisi Unified Modelling Language (UML) Menurut Nugroho (2015:6), "Unifield Modeling Language (UML) adalah 'bahasa' pemodelan untuk sistem atau perangkat lunak yang berparadigram 'berorientasi objek'. Pemodelan (modeling) sesungguhnya 41 digunakan untuk penyederhanaan permasalahan-permasalahan yang kompleks sedemikian rupa sehingga lebih mudah dipelajari dan dipahami. Bahasa pemodelan grafis telah ada diindustri perangkat lunak sejak lama. Pemicu utama di balik semuanya adalah bahwa bahasa pemrograman berada pada tingkat abstraksi yang terlalu tinggi untuk memfasilitasi diskusi tentang desain. Dengan menggunakan notasi-notasi seperti UML, alur logika dari perangkat lunak yang akan dikembangkan bisa mudah untuk dipahami”.

Berdasarkan pendapat yang dikemukakan diatas dapat ditarik kesimpulan bahwa "Unified Modelling Language (UML) adalah sebuah bahasa yang berdasarkan grafik atau gambar untuk menvisualisasikan, menspesifikasikan, membangun dan pendokumentasian dari sebuah sistem pengembangan perangkat lunak berbasis objek (Object Oriented Programming)".

UML hanya berfungsi untuk melakukan pemodelan. Jadi penggunaan UML tidak terbatas pada metodologi tertentu, meskipun pada kenyataannya UML paling banyak digunakan pada metodologi berorientasi objek (Rosa dan Shalahudin, 2016:133)

\section{Diagram UML}

Menurut Rosa dan Shalahudin (2016:140), pada UML terdiri dari 13 macam diagram yang dikelompokkan dalam 3 kategori. Berikut ini penjelasan singkat dari pembagian kategori tersebut:

a. Struktur diagram, yaitu kumpulan diagram yang digunakan untuk menggambarkan suatu struktur statis dari sistem yang dimodelkan. Struktur diagram terdiri dari class diagram, objek diagram, komponen 
diagram, composite structure diagram, package diagram dan deployment diagram.

b.Behavior diagram yaitu kumpulan diagram yang digunakan untuk menggambarkan kelakuan sistem atau rangkaian perubahan yang terjadi pada sebuah sistem. Behavior diagram terdiri dari Use case diagram, Aktivity diagram, State Machine Sistem.

c. Interaction diagram yaitu kumpulan diagram yang digunakan untuk menggambarkan interaksi sistem dengan sistem lain maupun interaksi antar subsistem pada suatu sistem. Interaction diagram terdiri dari Sequence 13 Politeknik Negeri Sriwijaya Bab II Tinjauan Pustaka Diagram, Communication Diagram, Timing Diagram, Interaction Overview Diagram.

\section{Use Case Diagram}

Menurut Rosa dan Shalahudin (2016:155), "use case atau diagram use case merupakan pemodelan untuk kelakuan (behavior) sistem informasi yang akan dibuat". Use case mendeskripsikan sebuah interaksi antara satu atau lebih aktor dengan sistem informasi yang akan dibuat. Secara kasar, use case digunakan untuk mengetahui fungsi apa saja yang ada di dalam sebuah sistem informasi dan siapa saja yang berhak menggunakan fungsi-fungsi itu.

\section{Activity Diagram}

Menurut Rosa dan Shalahudin (2016:161), "diagram aktivitas atau activity diagram menggambarkan workflow (aliran kerja) atau aktivitas dari sebuah sebuah sistem atau proses bisnis atau menu yang ada pada perangkat lunak. Yang perlu di perhatikan disini adalah bahwa diagram aktivitas menggambarkan aktivitas sistem bukan apa yang dilakukan aktor, jadi aktivitas yang dapat dilakukan oleh sistem.

\section{Class Diagram}

Menurut Rosa dan Shalahudin (2016:141), “diagram kelas atau class diagram menggambarkan struktur sistem dari segi pendefinisian kelas-kelas yang akan dibuat untuk membangun sistem". Kelas memiliki apa yang disebut atribut dan method atau operasi. Berikut penjelasan atribut dan metode :
1) Atribut merupakan variable-variabel yang dimiliki oleh suatu kelas.

2) Operasi atau method adalah fungsi-fungsi yang dimiliki oleh suatu kelas.

\section{Sequence Diagram}

Menurut Rosa dan Shalahudin (2016:165), “diagram sekuen menggambarkan kelakuan objek pada use case dengan mendeskripsikan waktu hidup objek dengan massage yang dikirimkan dan diterima antar objek". Oleh karena itu untuk menggambarkan diagram sekuen maka harus diketahui objekobjek yang terlibat dalam sebuah use case beserta metode-metode yang dimiliki kelas yang diinstansiasi menjadi objek itu.

\section{PHP/CSS/XAMPP}

Fungsi XAMPP sendiri adalah sebagai server yang berdiri sendiri (localhost), yang terdiri beberapa program antara lain : Apache HTTP Server, MySQL database, dan penerjemah bahasa yang ditulis dengan bahasa pemrograman PHP dan Perl. Nama XAMPP sendiri merupakan singkatan dari $\mathrm{X}$ (empat sistem operasi apapun), Apache, MySQL, PHP dan Perl. Program ini tersedia dalam GNU General Public License dan bebas, merupakan web server yang mudah untuk digunakan yang dapat menampilkan halaman web yang dinamis. Untuk mendapatkannya XAMPP anda dapat mendownload langsung dari web resminya. Dan berikut beberapa definisi program lainnya yang terdapat dalam XAMPP.

Server HTTP Apache atau Server Web/WWW Apache adalah server web yang dapat dijalankan di banyak sistem operasi seperti (Unix, BSD, Linux, Microsoft Windows dan Novell Netware serta platform lainnya) yang berguna untuk melayani dan memfungsikan situs web. Protokol yang digunakan untuk melayani fasilitas web/www ini menggunakan HTTP.

MySQL adalah sebuah perangkat lunak sistem manajemen basis data SQL (bahasa Inggris: database management sistem) atau DBMS yang multithread, multi-user, dengan sekitar 6 juta instalasi di seluruh dunia. MySQL AB membuat MySQL tersedia sebagai perangkat lunak gratis dibawah lisensi GNU 
General Public License (GPL), tetapi mereka juga menjual dibawah lisensi komersial untuk kasus-kasus dimana penggunaannya tidak cocok dengan penggunaan GPL.

\section{PHP}

Hypertext Preprocessor adalah bahasa skrip yang dapat ditanamkan atau disisipkan ke dalam HTML. PHP banyak dipakai untuk memrogram situs web dinamis. PHP dapat digunakan untuk membangun sebuah CMS.

PhpMyAdmin adalah perangkat lunak bebas yang ditulis dalam bahasa pemrograman PHP yang digunakan untuk menangani administrasi MySQL melalui Jejaring Jagat Jembar (World Wide Web). phpMyAdmin mendukung berbagai operasi MySQL, diantaranya (mengelola basis data, tabel-tabel, bidang (fields), relasi (relations), indeks, pengguna (users), perijinan (permissions), dan lain-lain).Pada dasarnya, mengelola basis data dengan MySQL harus dilakukan dengan cara mengetikkan baris-baris perintah yang sesuai (command line) untuk setiap maksud tertentu. Jika seseorang ingin membuat basis data (database), ketikkan baris perintah yang sesuai untuk membuat basis data. Jika seseorang menghapus tabel, ketikkan baris perintah yang sesuai untuk menghapus tabel. Hal tersebut tentu saja sangat menyulitkan karena seseorang harus hafal dan mengetikkan perintahnya satu per satu.

\section{Metode Penelitian}

\section{Desain Penelitian}

Penelitian yang dilakukan oleh peneliti menggunakan metode kualitatif. Di mana metode pendekatan kualitatif menekankan pada makna, penalaran, definisi suatu situasi tertentu (dalam konteks tertentu), lebih banyak meneliti hal-hal yang berhubungan dengan kehidupan sehari-hari. Metode kualitatif juga mempelajari berbagai aspek kualitatif dari kehidupan sosial yang mencangkup ragam dimensi sosial dari tindakan dan keadaan hingga proses, dan peristiwa sebagaimana di mengerti dan berdasarkan kontruksi dan makna yang diorganisasikan oleh dan melalui praktek sosial.
Model yang digunakan dalam membangun sistem informasi ini adalah model waterfall yang didokumentasikan menggunakan UML (unifed modeling languange). Model waterfall yang digunakan dalam penelitian ini dibatasi hanya sampai pada tahap perancangan sistem.

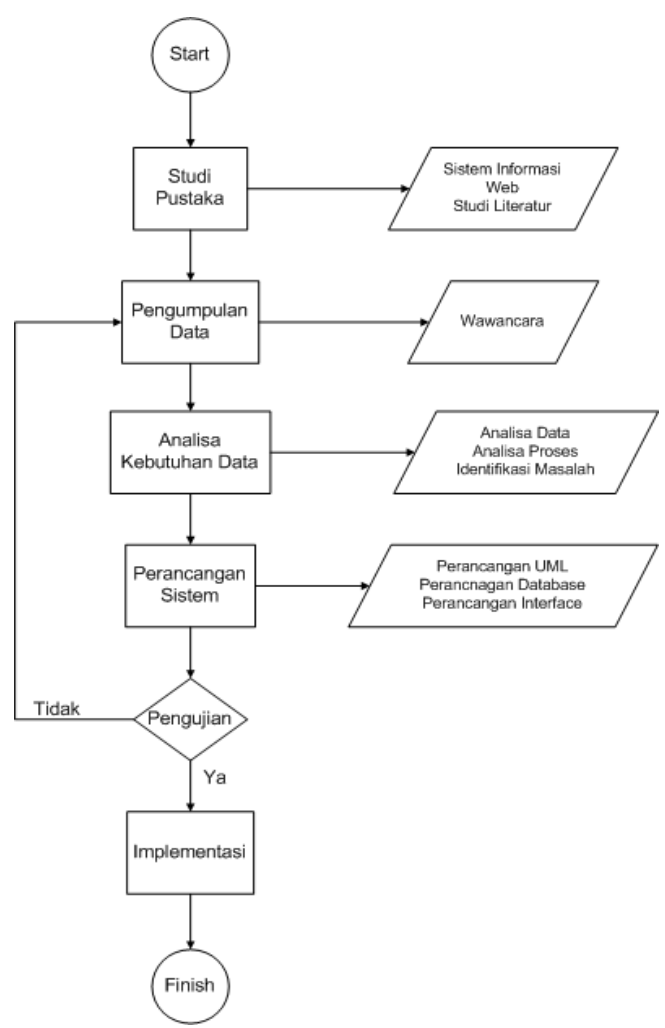

Gambar 1. Alur Penelitian

\section{Tahapan Penelitian}

a. Studi pustaka

Pada tahapan pertama penulis melakukan pengumpulan bahan pustaka sebagai acuan teori dan sebagai tinjauan yang digunakan untuk mengidentifikasi sistem informasi, dan sebagai acuan untuk merancang website ini.

b. Pengumpulan Data

Pada tahap kedua penulis melakukan pengumpulan data yang terkait dengan sistem informasi yang dibuat. Data yang didapatkan akan menjadi dasar dalam menganalisa dan merancang sistem yang akan dibuat. Tahap pengumpulan data dilakukan dengan wawancara dan mencari literatur yang terkait dengan sistem yang akan dibuat. 
c. Analisa Kebutuhan Sistem

Pada tahap yang ketiga, menjadi salah satu tahap yang penting dalam merancang sebuah sistem atau aplikasi karena pada tahap ini semua data yang sudah dikumpulkan pada tahap sebelumnya akan diseleksi untuk kemudian dibuat sebuah rancangan aplikasi. Hasil dari analisa merupakan racangan aplikasi yang akan digambarkan dalam bentuk UML dan dibuatkan Entity Relationship Diagram (ERD) yang menggambarkan bagaimana skema data dan informasi.

d. Perancangan

Pada tahapan yang ke empat, merupakan hasil dari tahapan analisa digambarkan dalam bentuk UML dan dibuatkan Entity Relationship Diagram (ERD) yang menggambarkan bagaimana skema data dan informasi akan disimpan kedalam suatu database. Pada tahap ini juga dirancang interface aplikasi Website Penyewaan Gedung Balai Komando.

e. Pengujian

Pada tahapan yang ke lima, merupakan tahap dimana sistem dan hasil analisa diuji untuk disesuakan dengan kebutuhan user jika sudah lengkap maka akan didokumentasikan.

f. Dokumentasi/Laproran

Tahap yang terakhir penulis melakukan dokumentasi dan penulisan laporan yang terkait dengan perancangn aplikasi.

\section{Proses Bisnis Sistem Berjalan}

Sebuah sistem memiliki beberapa elemen yang membuat sistem informasi tersebut dapat berjalan dengan baik. Tingkat keberhasilan sistem tersebut tergantung juga terhadap beberapa faktor, antara lain bagaimana alur kerja yang dilakukan oleh sebuah sistem, dokumen yang digunakan media penyimpanan data maupun informasi yang dihasilkan oleh sebuah sistem dokumen yang digunakan, media penyimpanan data maupun informasi yang dihasilkan oleh sebuah sistem.

Prosedur adalah serangkaian aksi yang spesifikasi tindakan atau operasi yang harus dijalankan atau didedikasi dengan cara yang baku (sama) agar selalu memperoleh hasil yang sama dari keadaan yang sama atau kegiatan yang tepat dari tahapan-tahapan yang menerangkan mengenai proses apa yangn dierjakan siapa yang mengerjakan proses terkait dan bagaimana_ating_itu dapat berjalan. Pelayanan peyewaan Gedung Serbaguna AlBarkah Bekasi merupakan inti dari pengelolaan sarana dan prasarana yang tersedia di Gedung Serbaguna.

Berikut uraian prosedur yang sedang berjalan di Gedung Serbaguna Al-Barkah, yaitu:

a. Prosedur proses pembuatan surat Perizinan sewa Gedung

1) Customer harus datang langsung ke kantor Gedung serbaguna Albarkah yang beralamatkan di Jl. Veteran No. 42, Marga jaya. Bekasi Selatan untuk melakukan pendaftaran dengan membawa surat permohonan penyewaan gedung kebagian pelayanan.

2) Lalu bagian pelayanan melakukan disposisi surat permohonan penyewaan gedung serbaguna tersebut, dan membuat keterangan yang berisi nama customer dan tujuan penyewaan, waktu dan tanggal acara, serta keterangan yang akan diisi oleh Ketua III (Ketua Umum atau Sekretaris daerah kota Bekasi), lalu surat permohonan sewa beserta surat keterangan tersebut akan diserahkan kepada ketua III.

3) Ketua III melakukan pemerikasaan surat permohonan sewa dan mengisikan surat keterangan yang berisikan instruksi atau tidak disetujuinya atas permohonan dari penyewa tersebut yang kemudian diserahkan kepada bagian organisasi dan SDM.

b. Prosedur proses transaksi pembayaran sewa gedung

1) Customer membawa surat perijinan penyewaan dan melakukan transaksi pembayaran kepada bagian pelayanan

2) Setelah melakukan transaksi pembayaran maka bagian pelayanan akan membuatkan bukti pemayaran berupa kwitansi yang diberikan kepada customer. 
3) Bagian pelayanan membuat laporan pemasukan sewa gedung sebagai arsip ke Ketua III.

\section{Diagram Activity Sistem Berjalan}

Terminology diagram activity sistem berjalan yaitu menggambarkan pandangan mengenai masukan, proses dan keluaran sistem yang berhubungan dengan masukan proses dan keluaran serta mempresentasikan dan menganalisis prosedur-prosedur mendetail dalam sistem yang lebih besar.

Diagram activity sistem berjalan juga mampu mengkonseptualisasikan bagaimana data-data berpindah didalam organisasi. Pada aliran data menekankan logika yang mendasari sistem.

Diagram activity penyewaan gedung serbaguna Al-Barkah sebagai berikut:

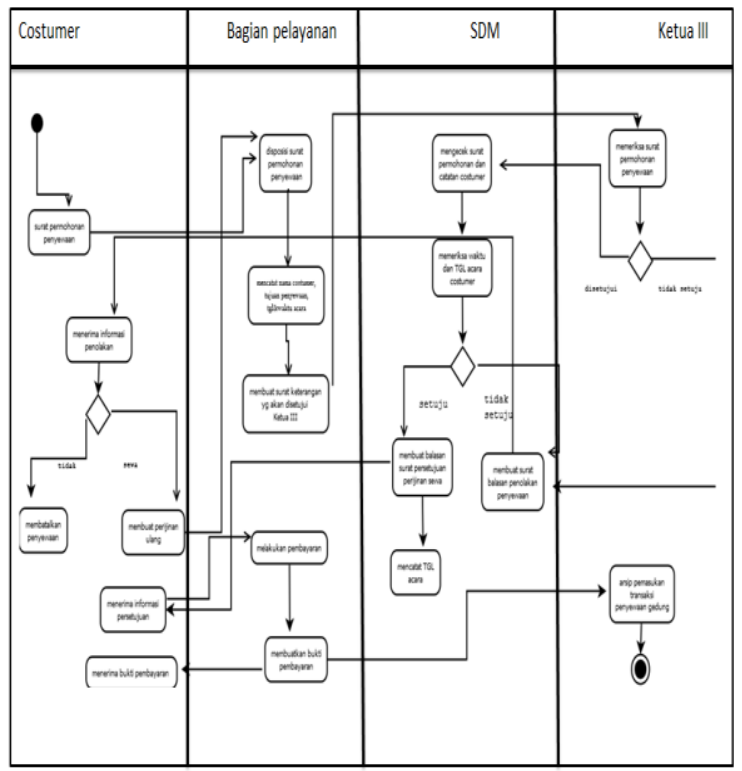

\section{Use Case Diagram}

Use case adalah deskripsi fungsi dari sebuah sistem dari perspektif petugas.

Use case merupakan diagram yang menggambarkan kemampuan sebuah sistem yang akan dijalankan.
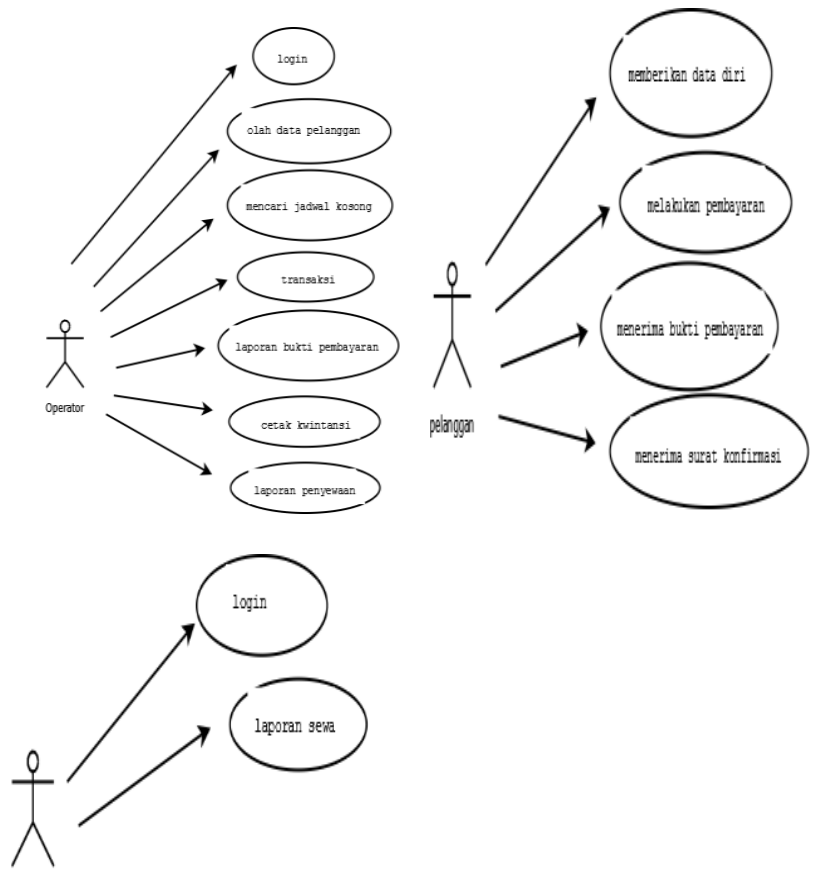

pemilik

\section{Spesikasi sistem berjalan}

Dalam spesifikasi sistem berjalan ini akan dijelaskan mengenai dokumen-dokumen yang terdapat dalam proses pencatatan datanya, dokumen-dokumen tersebut terdiri atas dokumen masukan dan dokumen keluaran.

\section{Spesifikasi Bentuk dokumen masukan}

1. Surat Permohonan Penyewaan gedung

Fungsi : Sebagai surat izin penyewaan Gedung Serbaguna Al-Barkah kebagian OSDM

Sumber : Customer

Distribusi : Customer OSDM

Rangkap : 1 (satu) lembar

Bentuk dokumen : Surat

Item :no_surat_permohonan, lampiran, perihal, hari, tanggal, waktu, nama_penyewa

2. Kwitansi

Fungsi : Sebagai tanda bukti pembayaran sewa gedung dan sebagai tanda jadi akan dilaksanakannya sebuah acara

Sumber : bagian pelayanan

Distribusi : bagian pelayanan-Customer

Rangkap : 2 (dua) lembar

Bentuk dokumen : Kwitansi 
Item :sudah_diterima_dari, banyaknya_uang,untuk_pemba yaran, jumlah

3. Data Pendapatan/Pemasukan Penyewaan Gedung Serbaguna

Fungsi : Sebagai dokumentasi data pemasukan/pendapatan yang diperoleh dari kegiatan penyewaan gedunng serbaguna Al-Barkah

Sumber : Bag. OSDM
Distribusi $:-$
Rangkap : 1 (satu) lembar
Bentuk dokumen $\quad$ Dokumen
Item $\quad: \quad$ no, hari, tanggal,
$\quad$ nama_gedung, jml_pemasukan

4. Laporan pemasukan sewa gedung

Fungsi : Sebagai dokumentasi atau akumulasi dana dari kegiatan penyewaan gedung

Sumber : bagian pelayanan

Distribusi : bagian pelayanan -Bendahara

Rangkap : 2 (dua) lembar

Bentuk dokumen : Laporan

Spesifikasi bentuk dokumen keluaran

1. Surat Perizinan Sewa Gedung

Fungsi : Sebagai tanda bukti izin penyewaan gedung telah disetujui

Sumber : Bag. Pelayanan

Distribusi : Bag. Pelayanan - Customer

Rangkap : 2 (dua) lembar

Bentuk dokumen : Surat

Item : no_surat_ijin, lampiran, perihal, hari, tanggal, waktu, ket_izinSG

2. Surat Penolakan Sewa Gedung

Fungsi : Sebagai tanda bukti

Sumber : Bag. pelayanan

Distribusi : Bag.Pelayanan - Customer

Rangkap : 1 (satu) lembar

Bentuk dokumen : Surat

Item : no_surat_penolakan, lampiran, perihal, hari, tanggal, waktu, ket_penolakanSG

3. Kwitansi

Fungsi : Sebagai tanda bukti pembayaran sewa gedung dan sebagai tanda jadi akan dilaksanakannya sebuah acara

Sumber : bagian pelayanan

Distribusi : bagian pelayanan-Customer

Rangkap : 2 (dua) lembar

Bentuk dokumen : Kwitansi

Item : sudah_diterima_dari, banyaknya_uang,untuk_pemba yaran, jumlah

4. Jadwal pemakaian Gedung

Fungsi : Sebagai informasi jadwal gedung

Sumber : Bag. pelayanan

Distribusi :-

Rangkap : 2 (dua) lembar

Bentuk dokumen : Dokumen

Item : no, hari, tanggal, jam, nama_penyewa,

acar_kegiatan, keterangan.

\section{Rancangan Sistem Usulan}

Rancangan model logic, penulis menggunakan UML (Unified Modeling Language) karena pemodelan ini dibuat dengan pendekatan yang berorientasi objek. Ada beberapa tahap proses untuk merancang sebuah model yang handal menggunakan metode perancangan yang berorientasi objek. Diagram yang akan digunakan pada penelitian ini adalah Use Case Diagram, dan Activity Diagram

a. Identifikasi Pelaku/Aktor

Pelaku/Aktor yang terdapat pada web penyewaan gedung balai komando terdapat tiga aktor yang terlibat, selengkapnya dapat diketahui dari tabel berikut.

Tabel 1 Daftar Istilah Aktor atau Pelaku system usulan

\begin{tabular}{|l|l|lr|}
\hline No & Istilah & \multicolumn{2}{|c|}{ Deskripsi } \\
\hline 1 & Admin & $\begin{array}{l}\text { Individu yang mengurus } \\
\text { pengelolaan }\end{array}$ \\
& & data \\
& & fasilitas tambahan yang \\
& & dibutuhkan, yedung, \\
& & pembayaran \\
\hline
\end{tabular}




\begin{tabular}{|l|l|l|}
\hline No & Istilah & \multicolumn{1}{|c|}{ Deskripsi } \\
\hline 2 & $\begin{array}{l}\text { Konsu } \\
\text { men }\end{array}$ & $\begin{array}{l}\text { Individu yang dapat } \\
\text { melihat data fasilitas yang } \\
\text { ada, catering yang bekerja } \\
\text { sama, jadwal pemesanan } \\
\text { yang masih } \\
\text { tersedia. }\end{array}$ \\
\hline 3 & $\begin{array}{l}\text { Danden } \\
\text { ma }\end{array}$ & $\begin{array}{l}\text { Individu yang } \\
\text { bertanggung jawab atas } \\
\text { semua kegiatan yang } \\
\text { dilakukan di dalam } \\
\text { penyewaan gedung. }\end{array}$ \\
\hline
\end{tabular}

\section{b. Use Case}

Diagram use case mengambarkan aktifitas yang dilakukan oleh suatu sistem dari sudut pandang pengamatan luar. Apa yang dilakukan oleh aktor yang terlibat dalam sistem ini. Setelah use case dan aktor telah di indentifikasi langkah berikutnya yang harus dilakukan adalah membuat diagram use case. Apa yang dilakukan oleh aktor yang terlibat pada sistem ini, berikut ini adalah use case website penyewaan gedung.

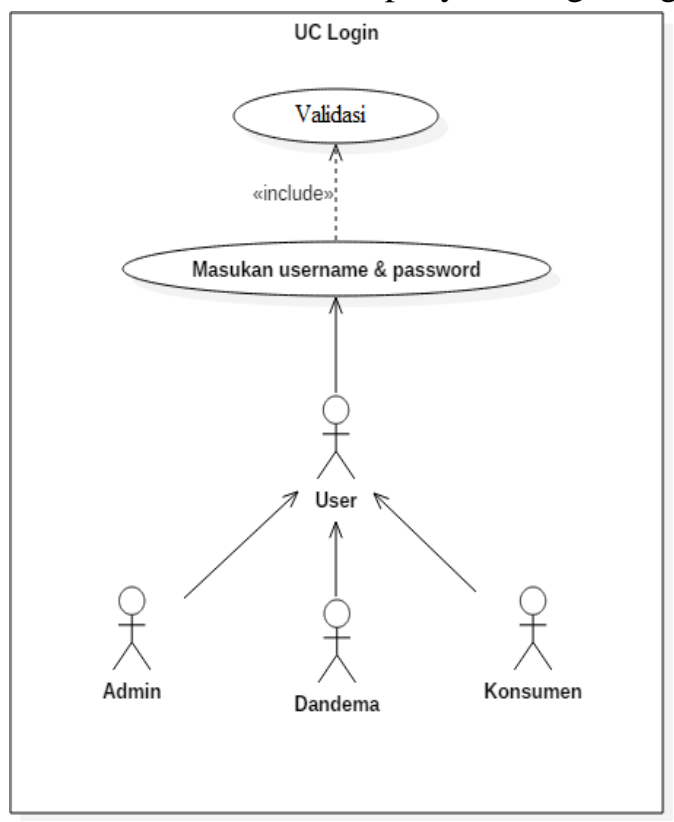

Gambar 2 Use Case Login

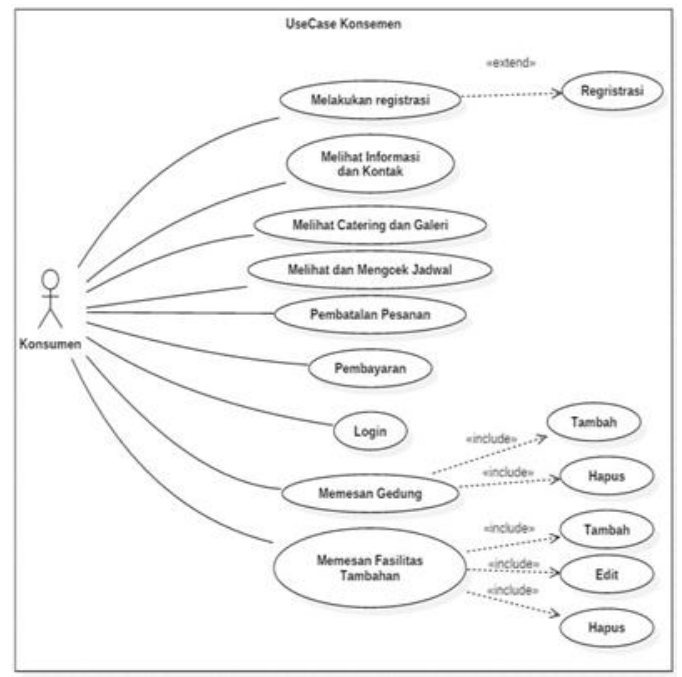

Gambar 3 Use Case Konsumen

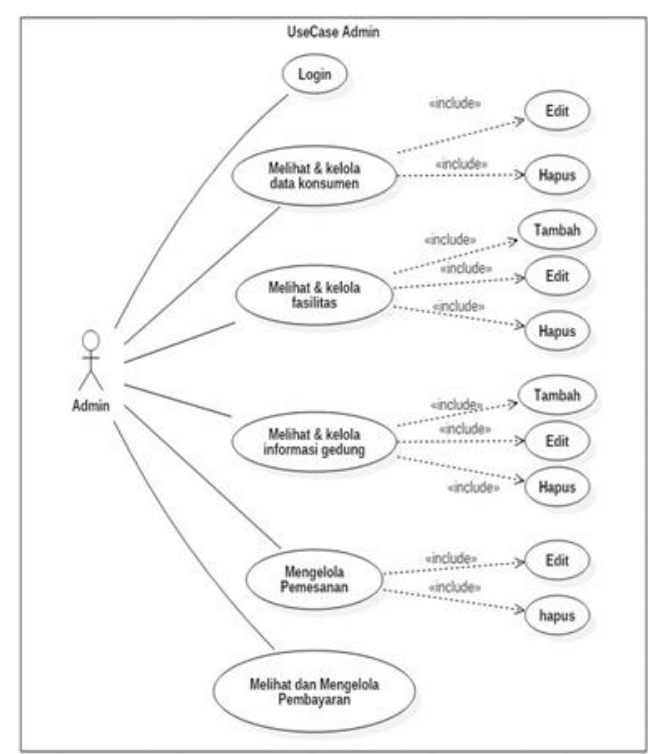

Gambar 4 Use Case Admin

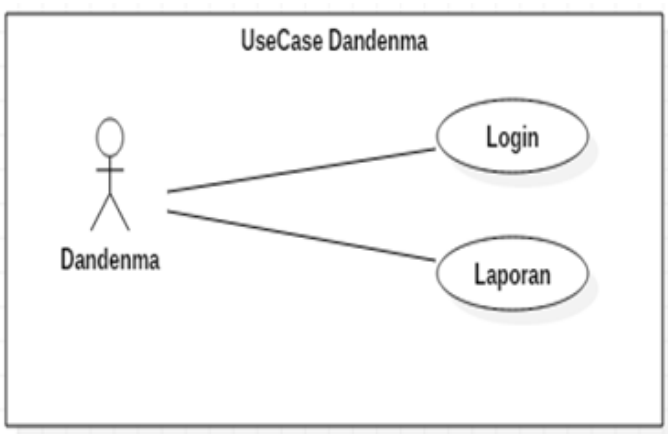

Gambar 5 Use Case Dandenma 
c. Class Diagram

Class diagram merupakan yang berikan pandangan secara luas dari suatu sistem dengan menunjukan kelas-kelasnya dan hubungan mereka. Kelas diagram bersifat statis dan menggambarkan hubungan apa yang terjadi. Berikut adalah kelas diagram Penyewaan Gedung Al-Barkah.

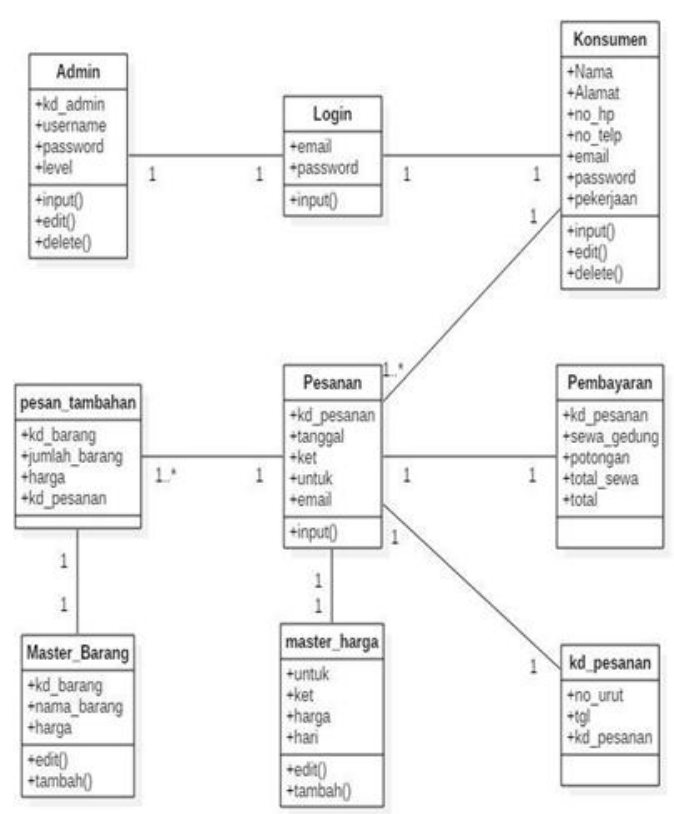

Gambar 6 Class Diagram

\section{Hasil Dan Pembahasan}

Hasil dari permasalahannya adalah:

1. Pada penyimpanan data masih menggunakan kertas jika dengan menggunakan sistem yang terkomputerisasi yang menggunakan database, tempat penyimpanan hanya membutuhkan hardisk computer/laptop saja dan data pun lebih terjaga dan dalam pencarian lebih efisien

2. Hasil dari transaksi masih menggunakan kwitansi yang ditulis tangan, jika dengan menggunakan sistem yang terkomputerisasi maka kegiatan transaksi dapat diproses lebih cepat dan hasil yang didapat dalam pembuatan bukti pembayaran akan lebih akurat

3. Untuk kekhawatiran yang tidak diinginkan dalam penjadwalan sewa gedung jika dengan menggunakan sistem yang terkomputerisasi maka data dan informasi penjadwalan dapat dilakukan dengan benar dan informasi yang akan disampaikan ke customer lebih akurat.

4. Dalam pembuatan laporan-laporan keuangan sangatlah dibutuhkan ketelitian agar tidak terjadinnya kesalahan informasi, jika dengan sistem yang terkomputerisasi maka kesalahan-kesalahan akan berkurang sehingga informasi yang diberikan lebih akurat.

Dengan dikembangkannya pembuatan sistem informasi pelayanan penyewaan Gedung serbaguna Al-Barkah yang terkomputerisasi diharapkan kekurangan dan kelemahan pada sistem informasi pelayanan penyewaan Gedung Serbaguna dapat teratasi dengan baik. Dan disini kami mencoba untuk memecahkan masalah dalam penyewaan gedung Masjid Albarkah dengan menggunakan sistem komputer yang kami buat sendiri menggunakan XAMPP-PHP MyAdmin-Mysql, seperti gambar berikut :

1. Spesifikasi Dokumen Masukan dengan Menggunakan Sistem Komputer

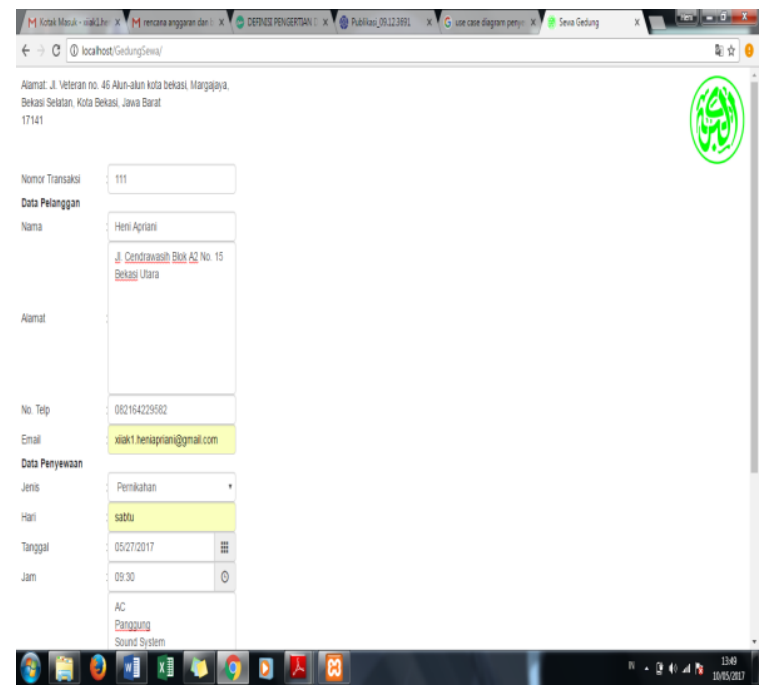




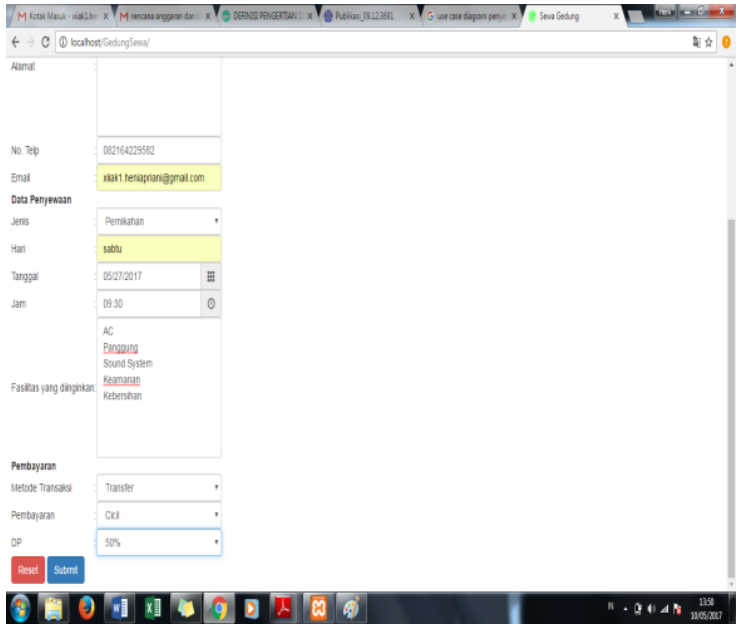

2. Spesifikasi Bentuk Dokumen Keluaran dengan Menggunakan Sistem Komputer

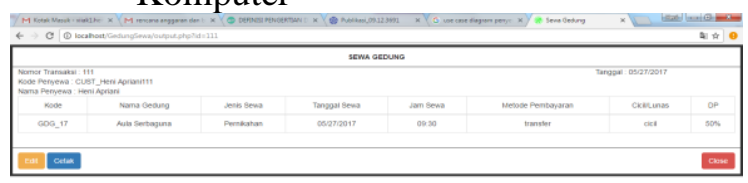

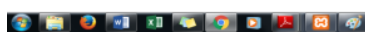

3. Rincian pembayaran cicilan costumer

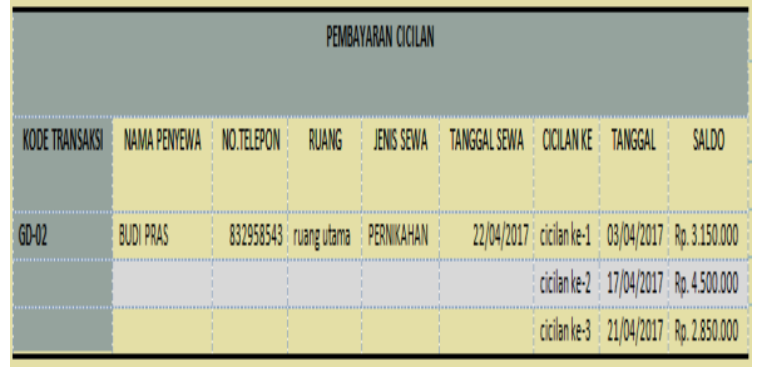

4. Rekap penyewaan gedung pertahun

\begin{tabular}{|c|c|c|c|c|c|c|c|c|c|}
\hline \multicolumn{10}{|c|}{ Relap Penvenazan Gedung Sewa } \\
\hline $\begin{array}{l}\text { lode } \\
\text { transsidi }\end{array}$ & กรma peñera & $\begin{array}{c}\text { no. } \\
\text { Teleponon }\end{array}$ & nom? & jenisewa & $\begin{array}{l}\text { trogeal } \\
\text { sevela }\end{array}$ & jam sera & metode pembajarn & $\begin{array}{l}\text { tasilits } \\
\text { tarbohin }\end{array}$ & totd \\
\hline GOO1 & NaZRRAYYN & 899838921 & gedung gerbogyna & SENITR & $03 / 202 / 2017$ & $\begin{array}{l}0800- \\
1100\end{array}$ & TVNA & todk bda & Rp. 2500000 \\
\hline $\operatorname{CONO}$ & BDO PRAS & 832558513 & rvargy uama & PENKAHAN & $2204 / 2017$ & $\begin{array}{l}0900- \\
12200\end{array}$ & TVHA & $\begin{array}{c}100 \\
3000000\end{array}$ & Re. 105000000 \\
\hline GOON3 & SATTKA LARA & 895355434 & gedung gerbagna & PENGAAAN & 29/04/2017 & $\begin{array}{l}1300- \\
16000\end{array}$ & TWHA & tods bda & Ap. 5000000 \\
\hline GOON & RYAN & 821943855 & gedungerbogna & SENIVR & $31 / 155 / 2017$ & $\begin{array}{l}13000 \\
16000\end{array}$ & TVKA & todk bdo & Ap.3500000 \\
\hline
\end{tabular}

\section{Kesimpulan dan Saran}

\section{Kesimpulan}

Berdasarkan hasil penelitian yang telah dilakukan oleh penulis, maka diperoleh kesimpulan, diantaranya:

1. Penyajian sistem informasi penyewaan gedung serbaguna yaitu dari cara pemesanan, pembayaran yang masih dilakukan secara manual bisa terdapat resiko kesalahan dalam pencatatan, maka lebih baik jika dibuatkan sebuah sistem untuk penyewaan gedung.

2. Sistem yang dibuat sedikit banyak dapat membantu dalam mengelola penyewaan gedung serbaguna.

\section{Saran}

Adapun saran yang dapat diberikan penulis dalam sistem yang telah dibuat adalah sebagai berikut:

1. Sistem informasi yang dirancang ini tidak sampai proses berbasis web, untuk itu pengembangan selanjutnya system penyewaannya dapat dikembang menjadi bebabasis web.

2. Sebaiknya dibuatkan aturan dalam menggunakan sistem informasinya.

3. Sistem ini dapat dikembangkan lagi dengan aplikasi yang menyajikan fitur-fitur tambahan yang lebih baik dan menarik. Karena terbatasnya waktu pembuatan aplikasi ini ada beberapa keinginan masyarakat yang tidak dapat diwujudkan oleh penulis.

4. Saat ini sistem informasi terbatas pada penyewaan gedung saja, untuk pengembangan selanjutnya penyewaan dapat di tambah dengan menambahkan jasa catering dan terima jasa kartu undangan dapat di pesan dalam satu paket.

\section{Daftar Pustaka}

Adi Nugroho. Rekayasa Perangkat Lunak Berbasis Objek dengan Metode. USDP. Jogyakarta. 2016 
Hartono, Bambang. Sistem Informasi Manajemen Berbasis Komputer. Rineka Cipta. Jakarta. 2016

Jogiyanto. Analisis \& Desain Sistem Informasi : Pendekatan terstruktur teori dan praktik aplikasi bisnis. Andi Offset. Yogyakarta. 2015

Jogiyanto. Metodologi penelitian bisnis. BPFE. Yogyakarta. 2016

Rosa, Shalahudin. Rekayasa Perangkat Lunak. Graha ilmu. Yogyakarta. 2016

Suwardjono. Teori Akuntansi : pengungkapan dan saran interpretative. BPFE. Yogyakarta. 2016 